\title{
Efek Cuka Apel dan Cuka Salak terhadap Penurunan Glukosa Darah dan Histopatologi Pankreas Tikus Wistar Diabetes
}

\author{
Effects of Apple Vinegar and Salacca Vinegar on Reducing Blood Glucose and Pancreatic \\ Histopathology of Diabetic Wistar Rats
}

\author{
Elok Zubaidah, Izzati Nuril F \\ Jurusan Teknologi Hasil Pertanian Fakultas Teknologi Pertanian Universitas Brawijaya Malang
}

\begin{abstract}
ABSTRAK
Diabetes Melitus merupakan suatu penyakit metabolik yang terjadi karena kelainan sekresi insulin sehingga glukosa dalam darah mengalami peningkatan dan ditandai dengan perubahan progresif terhadap struktur histopathologi sel beta pankreas. Penelitian ini bertujuan untuk membandingkan pemberian cuka apel dan cuka salak terhadap glukosa darah serta perubahan histopathologi pankreas pada tikus wistar jantan yang telah diinduksi streptozotocin (STZ). Penelitian dilakukan dengan Post Test Only Control Group Design. Tikus dibagi dalam 4 kelompok perlakuan yang terdiri dari 4 ulangan yaitu kelompok normal (P0), kelompok diabetes (P1), kelompok diabetes+cuka apel (P2), dan kelompok diabetes+cuka salak (P3). Hasil penelitian menunjukkan bahwa cuka salak memiliki kemampuan menurunkan gula darah tikus diabetes sebesar 38,38\% lebih tinggi dibanding cuka apel, yakni sebesar 33,07\%. Hasil pengamatan histopathologi pangkreas diabetes dengan pemberian cuka salak menunjukkan adanya perbaikan sel endokrin yang menyebar di pulau Langerhans, kondisi sel beta dan sel alfa dalam keadaan relatif baik dibandingkan dengan kelompok diabetes yang diberi cuka apel yang masih ditemukan adanya ruang ruang kosong pada jaringan.
\end{abstract}

Kata Kunci: Cuka apel, cuka salak, histopatologi pankreas, penurunan glukosa darah, tikus diabetes

\section{ABSTRACT}

Diabetes Mellitus is a metabolic disease that occurs due to abnormal secretion of insulin, so glucose in the blood increases and is characterized by progressive changes in the structure of the pancreatic beta cell histopathology. This research aims to compare the effects of apple vinegar and salacca vinegar administration on blood glucose and pancreatic histopathology changes in male Wistar rats induced by streptozotocin (STZ). The research was performed by Post Test Only Control Group Design. Sample was divided into four treatments groups that consist of four repetitions, i.e. normal group $(P 0)$, diabetes group (P1), diabetes+apple vinegar group (P2), and diabetes+salacca vinegar group (P3). The results show that salacca vinegar is able to lower the blood sugar of diabetic mice (38,38\%), higher than the apple vinegar (33,07\%). Observation on diabetes pancreatic histopathology with salacca vinegar administration showed an improvement of endocrine cells spread in the islets of Langerhans, the condition of beta cells and alpha cells is in a relatively good state compared to the diabetic group given apple vinegar where empty spaces are found.

Keywords: Apple vinegar, diabetic mice, pancreas histopathology, reducing blood glucose, salacca vinegar

Jurnal Kedokteran Brawijaya, Vol. 28, No. 4, Agustus 2015; Korespondensi: Elok Zubaidah. Jurusan Teknologi Hasil Pertanian Universitas Brawijaya Malang Tel.(0341)569214Email:elzoeba@yahoo.com, elok@ub.ac.id 


\section{PENDAHULUAN}

Diabetes Mellitus merupakan penyakit metabolik yang prevalensinya meningkat dari tahun ke tahun (1). Diabetes Mellitus ditandai dengan keadaan hiperglikemia kronik disertai berbagai kelainan metabolik akibat kelainan sekresi insulin, penurunan sensitifitas reseptor insulin atau keduanya (2). Penyakit diabetes berhubungan dengan karakteristik dan perubahan progresif terhadap struktur sel beta pankreas yang terjadi secara kuantitatif (pengurangan jumlah atau ukuran) dan kualitatif (nekrosis, degenerasi, dan amydosis). Perubahan ini dapat dibuktikan melalui foto jaringan pankreas (3). Konsumsi diet dan pengobatan yang tepat dibutuhkan untuk mencegah semakin meningkatnya jumlah penderita diabetes. Akan tetapi, pengobatan kimia dapat memberikan efek samping, seperti terjadinya hipoglikemia, mual, rasa tidak enak di perut, dan anoreksia. Oleh sebab itu para ahli merekomendasikan agar dilakukan penelitian terhadap bahan alami yang memiliki efek samping minimal dibandingkan pengobatan kimia sehingga dapat menurunkan kadar gula darah (4).

Cuka merupakan cairan yang diproduksi oleh bahan yang mengandung pati dan gula melalui dua tahap fermentasi alkoholik dan acetous yang paling sedikit mengandung $4 \%$ (b/v) asam asetat. Asam asetat yang terkandung dalam cuka memiliki kemampuan untuk memperlambat enzim disakaridase dalam proses metabolisme karbohidrat sehingga dapat menurunkan glukosa dalam darah (5). Kombinasi antara kandungan asam asetat, senyawa aktif flavonoid serta antioksidan yang terkandung dalam cuka buah diduga dapat mencegah reaksi oksidatif sehingga dapat memperbaiki kerusakan sel beta pankreas dan meningkatkan sekresi insulin. Cuka apel atau Apple vinegar merupakan hasil dari fermentasi alami buah apel murni yang memiliki antioksidan seperti flavonoid. Menurut Abu-Zaiton pemberian cuka apel pada tikus diabetes dapat menurunkan kadar glukosa darah, diduga cuka apel memiliki senyawa yang menyerupai sulfonylurea yang dapat menstimulasi sel beta pankreas untuk meningkatkan produksi insulin (6). Cuka salak (Salacca vinegar) merupakan cuka yang dibuat dengan bahan baku buah salak yang memiliki kemampuan fungsional lebih tinggi dari pada cuka apel. Cuka salak mengandung senyawa antioksidan alami yang dibuktikan dengan kemampuan cuka salak dalam menurunkan kadar gula darah tikus yang diberi diet tinggi gula (7).

Penelitian tentang kemampuan cuka salak dan cuka apel dalam menurunkan glukosa darah dan memperbaiki kerusakan sel beta pankreas belum pernah dilakukan. Oleh sebab itu diperlukan penelitian lebih lanjut mengenai perbandingan efek cuka salak dan cuka apel terhadap kadar glukosa darah serta histopatologi pankreas pada tikus wistar jantan yang telah mengalami diabetes mellitus (diinduksi dengan streptozotocin).

\section{METODE}

\section{Bahan dan Alat}

Cuka Apel yang digunakan dalam penelitian ini berasal dari cuka apel komersial merek " $\mathrm{A}$ " yang diperoleh dari Apotek Kawi sedangkan cuka salak merk Salacca Vinegar dari hasil penelitian di laboratorium mikrobiologi Pangan THP, pakan standar tikus (Comfeed PAR-S 67\%, Tepung terigu 33\% dan air), Streptozotocin. Hewan coba yang digunakan adalah 16 ekor tikus putih Rattus Novergicus Strain Wistar, dewasa yang berumur 3-4 bulan, berat badan 110-170 gram dengan kondisi sehat yang ditandai dengan gerakannya aktif. Alat yang digunakan dalam penelitian adalah spuit (Onemed), Glukometer (Omega), kandang tikus, sentrifuge, tabung falcon (eppendorf), mikropipet (Onemed), timbangan (Ohaus).

\section{Metode Percobaan}

Pemilihan objek penelitian untuk pengelompokan dan pemberian perlakuan menggunakan Rancangan Acak Lengkap dengan 4 kelompok perlakuan yaitu: Kelompok (PO): tikus normal (kontrol negatif) Kelompok (P1): tikus diabetes (kontrol positif) Kelompok (P2): tikus diabetes+cuka apel dosis $0,7 \mathrm{cc}$ Kelompok (P3): tikus diabetes+ cuka salak dosis 0,7 cc

\section{Persiapan Hewan Percobaan}

Hewan percobaan dikelompokkan menjadi 4 kelompok dan masing-masing kelompok terdiri dari 4 ekor. Setiap kelompok dipisahkan dalam kandang yang berbeda. Sebelum perlakuan tikus diadaptasikan pada kondisi laboratorium selama 1 minggu dengan tujuan untuk menyesuaikan dengan lingkungan. Selain adaptasi, juga diberikan diet normal (standar).

\section{Penentuan Besar Dosis Perlakuan}

Dosis cuka yang biasa dipakai oleh manusia adalah $3 \times 2$ $\mathrm{sdm}=2 \mathrm{sdm}$ cuka $=20 \mathrm{cc}$. Dosis pemakaian untuk tikus dapat dihitung dengan mengkalikan dosis pemakaian pada manusia tersebut dengan faktor konversi manusia ke tikus yaitu 0.0054 , sehingga didapat dosis pemakaian untuk tikus dengan berat $150 \mathrm{~g}$ sebagai berikut: $0.0054 \mathrm{cc} / \mathrm{g} \mathrm{BB}$ tikus $\times 150 \mathrm{~g}=0.81 \mathrm{cc} /$ ekor/hari. Dosis yang diberikan adalah $0,7 \mathrm{cc}$. Hal ini didasarkan pada penelitian sebelumnya yang memberikan cuka salak dosis $0,7 \mathrm{cc}$ didapatkan penurunan kadar glukosa darah. Cuka diberikan dengan pengenceran 2cc akuades pada setiap dosis pemberian. Pengenceran cuka dilakukan setiap hari.

\section{Pengukuran Kadar Glukosa Darah dan Berat Badan}

Pengukuran kadar glukosa darah semua tikus wistar dilakukan pada hari ke 0, 7, 14, 21, dan 28 dengan glukometer yaitu dengan mengambil 0,5ml darah dari ekor tikus. Pada hari ke 28 dilakukan proses pembedahan untuk mengambil darah dari jantung dan dilakukan pengambilan serum darah untuk pemeriksaan terhadap kadar glukosa darah akhir perlakuan dengan metode GOD PAP serta pengambilan jaringan pankreas untuk dilakukan foto histopatologi. Selain pengukuran kadar glukosa darah, penimbangan berat badan juga dilakukan pada hari ke 0,7 , 14, 21, dan 28 untuk memantau berat badan selama perlakuan berlangsung.

\section{Analisa Data}

Data dianalisa statistik menggunakan analisis ragam (ANOVA) dan apabila menunjukkan perbedaan maka diuji lanjut menggunakan uji beda BNT dengan selang kepercayaan $1 \%$.

\section{HASIL}

\section{Kandungan Cuka Apel dan Cuka Salak}

Cuka apel dan cuka salak merupakan cuka buah yang diproduksi dengan bantuan Saccaromyces cereviseae yang mengubah gula dan karbohidrat yang ada dalam bahan untuk menghasilkan alkohol dan Acetobacter acetii yang mengubah alkohol menjadi asam asetat. Adapun kandungan cuka apel dan cuka salak yang digunakan dalam 
penelitian ini dapat dilihat pada Tabel 1.

Tabel 1. Hasil analisa komponen yang terkandung dalam cuka apel dan cuka salak

\begin{tabular}{lrr}
\hline \multicolumn{1}{c}{ Komposisi } & Cuka Apel & Cuka Salak \\
\hline Total asam (titrasi) & $3,62 \%$ & $3,49 \%$ \\
pH & 2,73 & 3,19 \\
Aktivitas Antioksidan & $57,73 \%$ & $43,16 \%$ \\
Total Fenol & $135,38 \mathrm{mg} / \mathrm{L}$ & $229,67 \mathrm{mg} / \mathrm{L}$ \\
Asam Asetat & $7,41 \%$ & $3,54 \%$ \\
\hline
\end{tabular}

Hasil analisa menunjukkan bahwa kandungan asam asetat yang dimiliki cuka apel 7,41\% sedangkan cuka salak $3,54 \%$. Adanya asam asetat ini diduga akan memberikan peran dalam pengaturan kadar glukosa darah. Selain adanya asam asetat, aktivitas antioksidan pada cuka apel dan cuka salak diduga dapat berperan dalam memperbaiki sekresi insulin.

Pengaruh Pemberian Cuka Apel dan Cuka Salak terhadap Kadar Glukosa Darah Tikus

Pasca dilakukan induksi STZ pada kelompok perlakuan P1,P2 dan P3, hewan coba diduga mengalami diabetes mellitus. Hal ini ditandai dengan adanya kenaikan kadar glukosa darah sebesar $>200 \mathrm{mg} / \mathrm{dl}$. Setelah induksi STZ dan tikus menderita diabetes mellitus kemudian dilakukan pemberian cuka apel dan cuka salak pada kelompok perlakuan P2 dan P3 yang dilakukan selama 28 hari. Kadar gula darah tikus selama perlakuan 28 hari dapat dilihat pada Gambar 1.

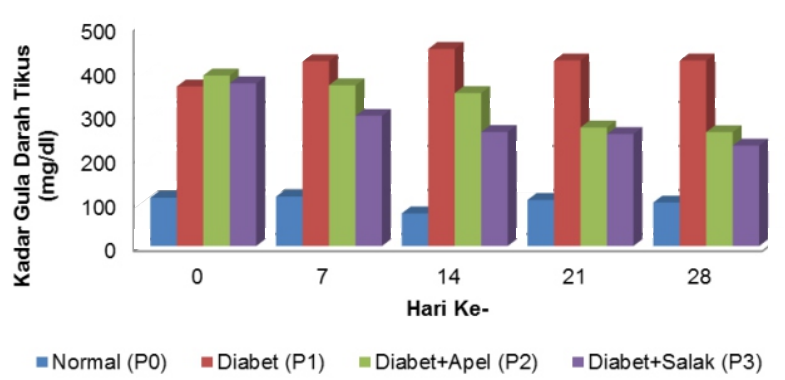

Gambar 1. Grafik kadar glukosa darah tikus selama perlakuan

Pada Tabel 2 terlihat bahwa terjadi perubahan kadar glukosa darah setelah perlakuan 28 hari. Penurunan yang paling tinggi terjadi pada kelompok tikus diabetes dengan pemberian cuka salak (P3) dengan presentase sebesar $38,38 \%$. Berdasarkan hasil analisa ragam, menunjukkan bahwa pada hari ke-0 kelompok (P1), (P2) dan (P3) berbeda nyata $(\alpha=0,01)$ terhadap kelompok tikus normal (P0). Terdapat perbedaan kadar glukosa darah pada kelompok normal dan kelompok yang perlakuan penyuntikan STZ. Pada hari ke-28 setelah perlakuan pemberian cuka, kadar gula darah pada kelompok (P2) dan (P3) berbeda nyata $(\alpha=0,01)$ terhadap tikus yang menderita diabetes tanpa perlakuan (P1). Kadar glukosa darah pada kelompok tikus pemberian cuka lebih rendah dibandingkan dengan kelompok tikus diabetes tanpa perlakuan, sedangkan kadar gula darah antara perlakuan pemberian cuka apel (P2) dan cuka salak (P3) tidak berbeda nyata.
Tabel 2. Rerata akumulasi kadar glukosa darah selama 28 hari perlakuan

\begin{tabular}{lccc}
\hline \multirow{2}{*}{ Kelompok perlakuan } & \multicolumn{3}{c}{ Kadar Glukosa Darah (mg/dl) } \\
\cline { 2 - 4 } & Hari Ke-0 & Hari Ke-28 & \% Perubahan \\
\hline Normal (P0) & $110^{\mathrm{a}}$ & $99^{\mathrm{a}}$ & 10 \\
Diabetes (P1) & $362^{\mathrm{b}}$ & $421^{\mathrm{c}}$ & $-16,02$ \\
Diabetes+Cuka Apel (P2) & $387^{\mathrm{b}}$ & $259^{\mathrm{b}}$ & 33,07 \\
Diabetes+Cuka Salak (P3) & $370^{\mathrm{b}}$ & $228^{\mathrm{b}}$ & 38,38 \\
\hline
\end{tabular}

Keterangan:

$*(-)=$ penurunan

$*(+)=$ kenaikan

*Angka yang diikuti oleh huruf yang berbeda menunjukkan hasil uji berbeda sangat nyata pada BNT $1 \%$

\section{Histopathologi Pankreas pada Tikus Percobaan}

Berdasarkan hasil pengamatan histopatologi pankreas tikus wistar (Gambar 3), dapat diketahui bahwa pada tikus normal tanpa perlakuan (PO), menunjukkan adanya keteraturan susunan sel endokrin yang menyebar di pulau Langerhans dengan bentuk sel yang seragam dan ukuran sitoplasma terlihat proporsional terhadap inti serta tidak mengalami perubahan. Selain itu kondisi sel-beta dan sel alfa dalam keadaan relatif baik yang ditandai dari kondisi islet langerhans yang relatif rapat. Sedangkan pada tikus diabetes (P1), menunjukkan adanya lesio pada sel jaringan pankreas berupa degenerasi sel endokrin yang menuju nekrosis sel.

Kondisi islet langerhans mengalami kerusakan yang ditandai dari adanya ruang-ruang kosong pada jaringan. Degenerasi sel endokrin terlihat pada intinya yang berubah bentuk menjadi polimorf (tidak seragam). Hal ini membuktikan bahwa pemberian STZ dapat merusak sel endokrin pankreas khususnya sel beta sehingga sekresi insulin ke dalam pembuluh darah menurun.
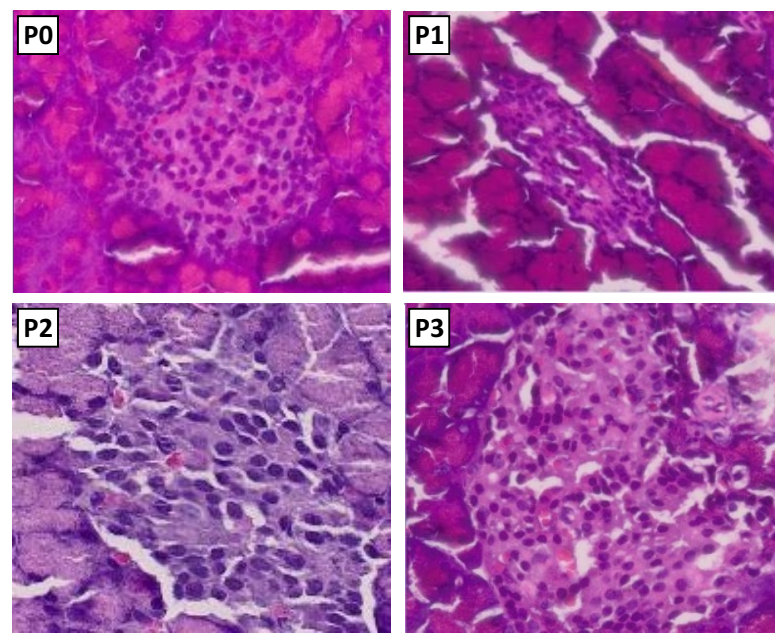

Gambar 3. Hasil pengamatan histopatologi pankreas pada 4 kelompok perlakuan.

Keterangan: (P0) tikus normal, (P1) tikus diabetes, (P2) tikus diabetes+cuka Apel, (P3) tikus diabetes+cuka salak

Ruang-ruang kosong pada islet langerhans disebabkan karena nekrosis dari sel beta (13). Perubahan-perubahan pada sel-sel yang ditimbulkan oleh zat-zat yang mempunyai efek sitotoksik yakni pengecilan pulau-pulau pankreas, pengurangan jumlah sel beta dan degranulasi, 
vakuolisasi daripada sel-sel tersebut. Pada kelompok perlakuan dengan cuka apel, masih ditemukan ruangruang kosong akan tetapi masih lebih baik dibandingkan dengan kelompok diabetes tanpa perlakuan. Sebaliknya pada kelompok dengan pemberian cuka salak, keadaan sel lebih baik dibandingkan dengan pemberian cuka apel. Akan tetapi keadaan islet Langerhans masih belum seperti keadaan pada kondisi sel pankreas normal. Diduga penyembuhan sel pankreas dengan pemberian cuka berlangsung lebih dari perlakuan selama 28 hari.

\section{Pengaruh Perlakuan terhadap Berat Badan Tikus}

Penghitungan rata-rata berat badan tikus dihitung baik sebelum perlakuan maupun sesudah perlakuan untuk mengetahui seberapa signifikan pengaruh dari pemberian cuka apel dan cuka salak selama 28 hari terhadap penurunan atau peningkatan berat badan tikus. Penimbangan berat badan tikus dilakukan pada hari ke 0 , $7,14,21$, dan 28 sehingga dapat diketahui kenaikan atau penurunan berat badan secara bertahap. Data hasil pengukuran berat badan tikus selama perlakuan penelitian dapat dilihat pada Gambar 4

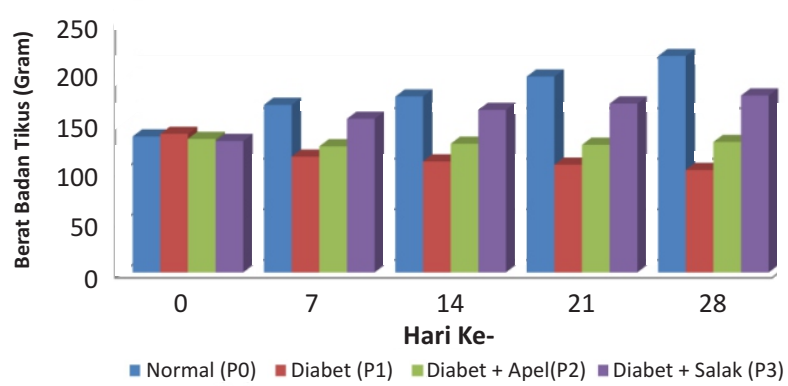

Gambar 4. Grafik rerata berat badan tikus

Berdasarkan Gambar 4 dapat dilihat bahwa dari kelompok tikus normal (P0) tanpa pemberian cuka selalu mengalami kenaikan berat badan setiap waktu penimbangan. Kenaikan berat badan yang terjadi cukup signifikan dan dapat dilihat bahwa berat badan dari tikus normal tanpa perlakuan ini paling tinggi jika dibandingkan dengan kelompok tikus lainnya. Pada kelompok tikus diabetes (P1), berat badan mengalami penurunan. Disisi lain pada kelompok tikus diabetes dengan pemberian cuka apel (P2), berat badan mengalami penurunan pada hari ke-14, namun kemudian mengalami kenaikan pada setiap minggunya. Pada kelompok tikus diabetes dengan pemberian cuka salak (P3). Adanya perbedaan berat badan pada tiap-tiap kelompok perlakuan diduga dapat disebabkan oleh pengaruh dari perlakuan yang diberikan serta perbedaan intake energi yang dihasilkan dari masing-masing perlakuan.

\section{DISKUSI}

Penurunan kadar glukosa darah pada kelompok diabetes+cuka apel (P2) dan diabetes+cuka salak (P3) diduga karena adanya kombinasi antara kandungan asam asetat dan antioksidan. Asam asetat yang terkandung dalam cuka buah diduga memberikan pengaruh terhadap kontrol glukosa darah dengan cara mempengaruhi laju pengosongan lambung. Konsumsi asam asetat yang terkandung dalam cuka tidak hanya untuk meningkatkan tapi juga memperpanjang rasa kenyang. Adanya rasa kenyang ini akan memperlambat respon metabolisme dalam tubuh sehingga akan meningkatkan respon atau sensitifitas insulin dalam merubah glukosa menjadi gula otot (8). Pemberian cuka apel pada pasien diabetes tipe 1 menunjukkan terjadi penurunan laju pengosongan lambung pasca pemberian cuka sehingga dapat terjadi kontrol kadar glukosa darah (9). Pemberian cuka selain mempengaruhi laju pengosongan lambung dan menghambat aktifitas enzim disakaridase, pemberian cuka diduga juga dapat meningkatkan sensitivitas insulin, menurunkan kadar glukosa pospandrial, dan menurunkan level resistensi insulin karena adanya kandungan zat seperti asam asetat (10).

Adanya penurunan kadar glukosa darah setelah perlakuan pemberian cuka apel diduga disebabkan oleh asam asetat yang dapat menurunkan laju pengosongan lambung sehingga sari-sari makanan lebih lambat diserap oleh usus dan peningkatan kadar glukosa darah dapat terkontrol (6). Pemberian cuka salak dapat menurunkan kadar glukosa darah tikus yang mengalami diabetes mellitus (8). Diduga asam asetat, antioksidan, dan senyawa lain saling berinteraksi untuk menurunkan dan mengontrol kadar glukosa dalam darah (8).

Senyawa lain yang dimiliki cuka apel dan cuka salak yang berperan sebagai antioksidan yaitu flavonoid, fitokimia dan tanin. Cuka Apel memiliki antioksidan sebesar 57,73\% dan cuka salak $23,16 \%$ dimana antioksidan ini diduga dapat berperan dalam kontrol glukosa darah kelompok diabetes. Senyawa flavonoid yang bermanfaat pada DM adalah melalui kemampuannya untuk menghindari absorpsi glukosa atau memperbaiki toleransi glukosa (11). Flavonoid menstimulasi pengambilan glukosa pada jaringan perifer, mengatur aktivitas dan ekspresi enzim yang terlibat dalam jalur metabolisme karbohidrat dan bertindak menyerupai insulin, dengan mempengaruhi mekanisme signaling insulin. Flavonoid pada cuka apel adalah quersetin yang dilaporkan memiliki kemampuan untuk memberikan perlindungan terhadap kerusakan sel yang diakibatkan oleh stress oxidative yang berhubungan dengan radikal bebas (11). Quersetin memperbaiki DM yang diinduksi streptozotocin dalam stress oksidatif (12). Tanin pada cuka salak berperan sebagai antioksidan yang diduga dapat menstimulus aktivitas transport glukosa yang pada akhirnya dengan peningkatan reseptor insulin akan dapat menurunkan kadar glukosa pada darah. Hasil pengamatan pewarnaan HE menunjukkan bahwa pemberian cuka buah relatif dapat memberikan efek perbaikan pulau Langerhans walaupun belum dapat mengembalikan ke kondisi normal. Bahan yang mengandung antioksidan dan dapat menurunkan radikal bebas terbukti dapat melindungi islet pankreas dari efek agen STZ (14). Dengan pemberian suatu antioksidan alkaloid dan flavonoid dapat merangsang pengeluaran insulin dari sel beta pankreas. Flavonoid dapat berperan dalam mengatur penurunan gula darah dan meningkatkan perbaikan distribusi sel beta penghasil insulin pulau Langerhans melalui pewarnaan hematoksilin-eosin (14). Mekanisme yang terjadi adalah antioksidan dapat mengikat superoksida sehingga dapat memperbaiki disfungsi endotel pada DM melalui fosforilasi oksidatif di dalam mitokondria. Hal ini yang akan menyebabkan terhambatnya komplikasi dari penyakit diabetes mellitus seperti penyempitan pembuluh darah, stroke, dan jantung (15). 
Rerata akumulasi berat badan selama 28 hari perlakuan, peningkatan berat badan yang paling tinggi adalah dari kelompok tikus normal. Pada kelompok tikus diabetes tanpa perlakuan pemberian cuka, terjadi penurunan berat badan selama perlakuan berlangsung yaitu $26,28 \%$. Hal ini diduga disebabkan karena kondisi tikus menderita diabetes mellitus menyebabkan terganggunya metabolisme karbohidrat, lemak dan protein sehingga mengakibatkan turunnya berat badan selama masa perlakuan. Pada penderita diabetes, walaupun kadar glukosa dalama darah tinggi tetapi sel tidak dapat memanfaatkan glukosa dalam darah sehingga untuk sumber tenaganya diambil dari otot ataupun hati melalui proses glukoneogenesis sehingga keadaan ini yang menyebabkan berat badan menurun. Pada kelompok dengan pemberian cuka apel terjadi penurunan berat badan selama perlakuan sebesar $2,27 \%$. Akan tetapi berdasarkan grafik rerata berat badan tikus, kelompok cuka apel mengalami peningkatan berat badan setelah hari ke-14 namun pada hari ke-28 berat badan belum menunjukkan kenaikan dibandingkan kondisi awal. Sedangkan pada kelompok cuka salak, terjadi kenaikan berat badan sebesar $34,61 \%$. Pemberian cuka salak, diduga dapat mengontrol berat badan. Kemampuan

\section{DAFTAR PUSTAKA}

1. Wild S, Roglic, G, Green, A, Sicree R, and King H. Global Prevalence of Diabetes; Estimates for the year 2000 and Projections for 2030. Diabetes Care. 2004; 27 : 1047-1053.

2. American Diabetes Association. Diagnosis and Classification of Diabetes Mellitus. Diabetes Care. 2013; 35(1): 64-71.

3. Szkudelski T. The Mechanism of Alloxan and Streptozotocin Action in B Cells of The Rat Pancreas. Physiological Research. 2001; 50(6): 537-546.

4. American Diabetes Association. Standards of Medical Care in Diabetes. Diabetes Care. 2005; 31(1): 12-54.

5. Liljeberg $\mathrm{H}$ and Bjorck I. Delayed Gastric Emptying Rate May Explain Improved Glycaemia in Healthy Subjects to A Starchy Meal With Added Vinegar. European Journal of Clinical Nutrition. 1998; 52(5): 368-371.

6. Abu-Zaiton AS. Effect of Apple Vinegar on Physiological State of Pancreas in Normal and Alloxan Induced Diabetic Rats. World journal of Zoology. 2011; 6(1): 07-11.

7. Zubaidah E. Pengaruh Pemberian Cuka Apel dan Cuka Salak terhadap Kadar Glukosa Darah Tikus Wistar Yang diberi Diet Tinggi Gula. Jurnal Teknologi Pertanian. 2011; 12(3): 163-169.

8. Pratiwi V. Efek Hipoglikemik pada Tikus Wistar Jantan diabetes yang Diinduksi dengan Streptozotocin Pasca Pemberian Cuka Salak (Salacca vinegar). [Skripsi]. Universitas Brawijaya, Malang. 2012.

9. Hlebowicz J, Darwiche G, Bjorgell O, and Almer LO. dalam mengontrol berat badan ini diduga terjadi karena adanya kombinasi antara penurunan laju pengosongan lambung oleh asam asetat dan senyawa antioksidan seperti tanin. Seperti halnya dengan kadar glukosa darah, kecepatan laju pengosongan lambung yang menurun akan memberikan efek kenyang dan mempengaruhi penyerapan sari-sari makanan oleh usus halus. Hal ini menyebabkan pelepasan glukosa ke dalam darah lebih lambat dan memperlambat rasa lapar yang timbul serta mencegah penumpukan lemak dan air di dalam tubuh (16).

Hasil penelitian menunjukkan bahwa terjadi penurunan kadar glukosa darah pada kelompok perlakuan diabetes+cuka salak yaitu $38,38 \%$ dan diabetes+cuka apel $33,07 \%$. Sebaliknya pada kelompok diabetes tanpa perlakuan terjadi kenaikan gula darah sebesar $16,02 \%$. Hasil pengamatan histopatologi untuk tikus dengan pemberian cuka menunjukan adanya perubahan pada selsel pankreas. Pada kelompok dengan pemberian cuka salak, keadaan sel lebih baik dibandingkan dengan pemberian cuka apel. Akan tetapi keadaan islet Langerhans masih belum seperti keadaan pada kondisi sel pankreas normal.

Effect of Apple Cider Vinegar on Delayed Gastric Emptying in Patients with Type I Diabetes Mellitus: A Pilot Study. BioMed Central Gastroenterology. 2007; 7:46.

10. Johnston CS, Kim CM, and Buller AJ. Vinegar Improves Insulin Sensitivity to a High-Carbohydrate Meal in Subjects with Insulin Resistance or Type to Diabetes. Diabetes Care. 2004; 27: 281-282.

11. Inawati. Pengaruh Ekstrak Biji Juwet terhadap Penurunan Glukosa Darah pada Mencit BALB/c Jantan yang Diinduksi Streptozotocin. [E-Library]. Universitas Wijaya Kusuma, Surabaya. 2011.

12. Mahesh T and Menon V. Quercetine Allievates Oxidative Stress in Stretozotocin-Induced Diabetic Rats. Phytotherapy Research. 2004; 18(2): 123-127.

13. Nurdiana, Soeharto S, dan Ali M. Efek Streptozotozin Sebagai Bahan Diabetogenik pada Tikus Wistar dengan Cara Pemberian Intraperitonial dan Intravena. Majalah Kedokteran Brawijaya. 1998; 14(2): 66-67.

14. Coskun O, Kanter M, Korkaz A, and Oter S. Quercetin, a Flavonoid Antioxidant, Prevent and Protectsts Streptozotozin Induced Oxidative Stress and Beta Cell Damage in Rat Pancreas. Pharmacological Research. 2005; 51(2): 117-123.

15. Shahab A. Antioksidan Dalam Menghambat Radikal Bebas. (Online) 2012. http://www. shahab.blogspot/ Antioksidan-dalam-Menghambat-radikal [diakses tanggal 27 Februari 2013].

16. Murphy R. Apple Cider Vinegar: A Universal Health Tonic. (Online) 2010. http://www.homeopathyblackheath.com/AppleCiderVinegar.pdf. [diakses tanggal 22 Oktober 2012]. 